\title{
Future hydropower production in the Lower Zambezi under possible climate change influence
}

\author{
Philipp Stanzel ${ }^{1 *}$ and Harald Kling ${ }^{1}$ \\ 1Pöyry, Hydropower and Renewable Energy, Water Resources Division, Laaer-Berg-Str. 43, 1100 Vienna, Austria
}

\begin{abstract}
Hydropower is the most important energy source in Mozambique and many other countries in southern Africa. Substantial hydropower development is planned for the Lower Zambezi for the next decades, with regional importance due to integration into the Southern African Power Pool. For such a long-term development, the possible impact of climate change on the future production is of essential interest. The objective of the presented study is to assess hydropower generation in the $21^{\text {st }}$ century for a future hydropower development scenario under two climate scenarios. The two climate scenarios represent a future wetting climate and a future drying climate, both with considerable warming, and are based on biascorrected data of two recent Global Climate Models. All hydro-meteorological input data are publicly available from an online decision support system, the Zambezi DSS. The future hydropower scenario considers the extension of the existing Cahora Bassa plant and three planned facilities downstream, Mphanda Nkuwa, Boroma and Lupata. Hydropower modelling for this cascade of reservoirs and hydropower plants is carried out with the HEC-ResSim model. Modelling results show a strong impact of precipitation projections on simulated future hydropower generation. With a wetting climate scenario, a marked increase of hydropower production of $+11 \%$ for a near-future period (2021-2050) and $+9 \%$ for a far-future period (2071-2100) are projected, as compared with simulation results for a historic reference scenario. In a drying climate, hydropower generation decreases by $-6 \%$ (near future) and $-13 \%$ (far future). The climate change impact is stronger for the large extended Cahora Bassa plant than for the smaller downstream facilities. The results show the importance of considering climate risk in technical design and financial assessment of hydropower projects in the region.
\end{abstract}

Keywords: Zambezi River, hydropower development, climate change, hydropower modelling, water resources

\section{INTRODUCTION}

Two of the world's largest reservoirs, Kariba reservoir and Cahora Bassa reservoir, are located along the Zambezi River. Energy supply in the region relies largely on hydropower production, providing over $70 \%$ of the energy generated in the countries of the Southern African Power Pool (excluding South Africa; SAPP, 2012). Cahora Bassa energy is invariably transmitted to South Africa almost entirely, and transnational energy transfer plays an increasing role within SAPP. With an expected growth in electricity demand of almost $40 \%$ until 2025 in the SAPP countries (SAPP, 2012), and a large remaining hydropower potential, hydropower development will continue to be one of the major resources of the Zambezi basin (World Bank, 2010a, Vol.3). Several hydropower projects are currently developed, planned and already partly under construction along the Zambezi and its tributaries (World Bank, 2010a, 2010b).

Changing climatic conditions, however, might impair the benefits of hydropower development. Future warmer temperatures will tend to decrease inflow due to higher land surface evapotranspiration and will increase reservoir evaporation. In addition, possible changes in precipitation patterns will affect runoff generation. Thus, climate change will impact hydropower, as it strongly depends on river discharge. According to Beilfuss (2012), the Intergovernmental Panel on Climate

To whom all correspondence should be addressed.

용 +4364482872 33, e-mail: philipp.stanzel@poyry.com Received 15 January 2014; accepted in revised form 5 September 2014.
Change (IPCC) expects the Zambezi basin to suffer the worst potential effects of climate change among 11 major Africa basins. Analyses of the impact of climate change on the terrestrial water cycle and, in consequence, on hydropower generation, are therefore of great relevance for water management and, in general, economic development in the region.

As reviewed by Beilfuss (2012), several investigations into the interrelation between climate change and hydropower development in the Zambezi basin have been conducted. Already, initial studies based on early results from climate modelling point towards a high sensitivity of hydropower generation to possible changes in climatic conditions (Salewicz, 1996; Urbiztondo 1992; IPCC, 2001). The more recent sensitivity tests of SWRSD (2010) also show strong effects of assumed higher evaporation and lower precipitation on the inflow to the existing reservoirs.

Yamba et al. (2011) investigated the combined effects of climate change and increased water demand on existing reservoirs. However, few studies have applied the latest generation climate models to investigate the effects of a future climate on future hydropower generation, including newly planned facilities. In their extensive economic investigation of the state and future of the Zambezi basin, the World Bank (2010a) also analyses hydropower production and includes the planned extension of Cahora Bassa and one new project, Mphanda Nkuwa (an alternative spelling is Mepanda Uncua). The impact of increasing temperatures, however, is investigated only for scenarios with important irrigation development, which leads to stronger effects from increased evaporation. Projected trends in precipitation are not considered. Beck (2010) and Beck and Bernauer (2010) apply scenarios that 


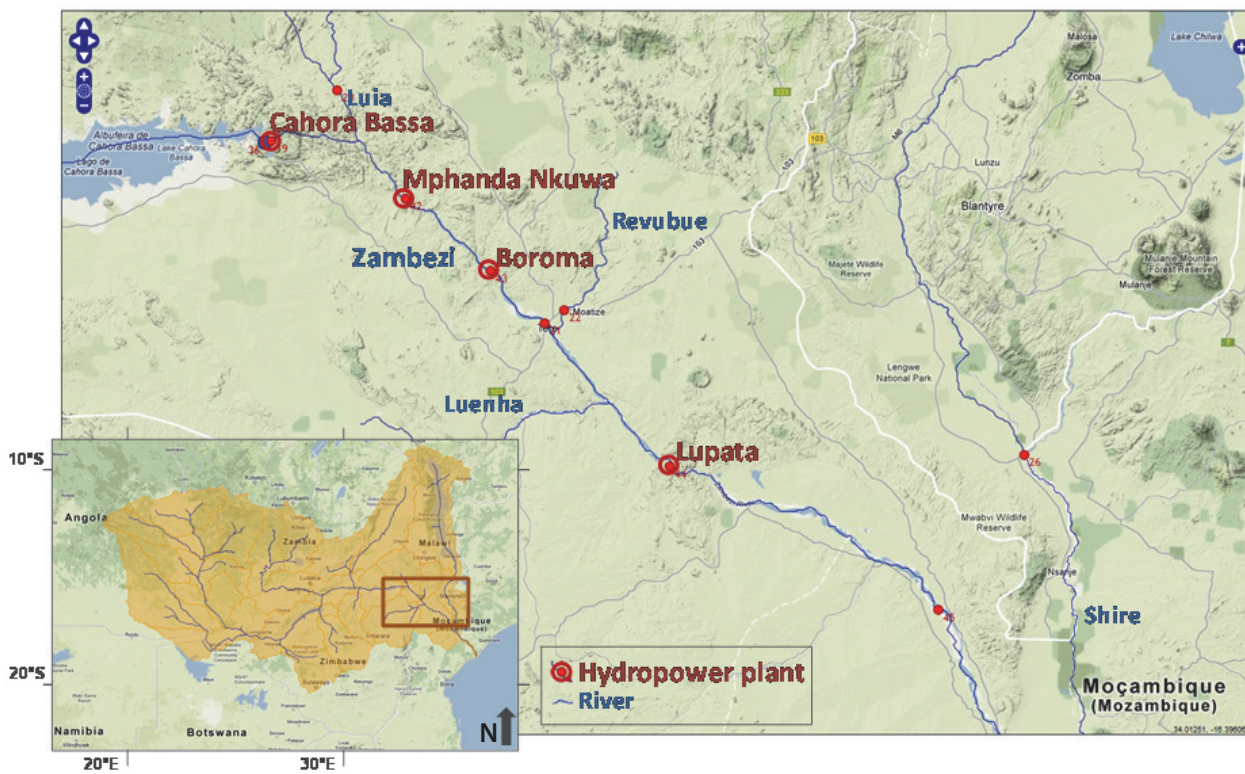

Figure 1

Study area:Zambezi basin and Lower Zambezi downstream of Cahora Bassa (adapted Zambezi DSS screenshots)

combine climatic changes and increasing water demand. They consider the four main future hydropower projects on the Lower Zambezi that are also the subject of the study presented here: Cahora Bassa extension, Mphanda Nkuwa, Boroma and Lupata. As water management development and climate change are considered simultaneously, direct impacts of changing climate conditions on hydropower production do not result from these analyses. Instead, the results strongly depend on the assumptions regarding future irrigation water demand. Kling et al. (2014) compare effects of the two main drivers of change on water availability in the Zambezi basin, climate change and irrigation development, and show that they have similar dimensions, but their analyses do not include an assessment of hydropower generation. The World Bank (2010b) specifically addresses climate change and hydropower, and also includes the four mentioned future projects, but only report overall trends for Mozambique. Therefore, in addition to existing studies, more detailed analyses of the impact of climate change on hydropower are needed (World Bank, 2010a, Vol.2).

The objective of this study is to increase the understanding of climate risk for hydropower production in the Zambezi basin. The analyses focus on possible effects of future climate change on future hydropower production in the Lower Zambezi in Mozambique. Detailed results for the entire cascade of future hydropower plants of Cahora Bassa, Mphanda Nkuwa, Boroma and Lupata are presented. The key research questions addressed are:

- How do plausible trends in precipitation in the $21^{\text {st }}$ century transform into trends in hydropower production?

- Can the negative effects of rising temperatures and increasing evaporation be compensated by increasing precipitation?

- Does climate change impact equally on any hydropower plant, or can different effects be expected for different facilities in a cascade of hydropower plants?

Climate change scenario simulations in this study rely on recent climate modelling results, including bias correction based on observed climate variables. All applied meteorological and hydrological input data sets for the entire Zambezi basin are publicly available in an online decision support system, the Zambezi DSS (INGC, 2014; Kling et al., 2014).
After specifying the study area, this paper gives an overview of the methods of reservoir operation and hydropower production modelling and of the generation of input data sets for scenario simulations. Then, the model skill for the simulation of historic hydropower production is analysed and detailed results of climate change scenario simulations are presented. The paper concludes with a discussion of these results and an outline of the main conclusions of the investigation.

\section{STUDY AREA}

The cascade of future hydropower plants (HPPs) under investigation is located in the Lower Zambezi River in Mozambique, downstream of the already existing Cahora Bassa reservoir (Fig. 1). The stretch of the Zambezi River from Cahora Bassa HPP to Lupata HPP is approximately $230 \mathrm{~km}$ long. Downstream of Cahora Bassa reservoir the Capoche/Luia River joins the Zambezi from the north. The Revubue River has its confluence with the Zambezi River at Tete and drains the area in the north-east to the Malawian border. Further downstream the Luenha River comes from Zimbabwe in the west. Downstream of the study area, the Shire River flows into the Zambezi River, draining almost the entire area of Malawi, including Lake Malawi.

For the simulation of inflow to Cahora Bassa reservoir, the entire upstream Zambezi basin with an area of around 1.064 million $\mathrm{km}^{2}$ is considered. At the most downstream of the considered HPPs, Lupata, the total catchment area is around 1.178 million $\mathrm{km}^{2}$. The Okavango River is not considered as a tributary of the Zambezi, as in other studies, even though in extremely wet years the Okavango system theoretically also discharges to the Zambezi. Mean annual rainfall of the period 1961-1990 in the Zambezi basin upstream of Lupata amounts to approximately $900 \mathrm{~mm}$, of which about $8 \%$ generates runoff and the remaining $92 \%$ is lost via evapotranspiration. The northern parts of the basin are wetter than the southern parts. Mean 1961-1990 runoff at Lupata is approximately $2800 \mathrm{~m}^{3} / \mathrm{s}$, with large seasonal and inter-annual variations. Seasonality in runoff is strongly controlled by seasonality in precipitation, which is highest during the austral summer from around December through March. During the dry season from May to September there is no significant precipitation. In addition to climatic variability, runoff retention in large floodplains and 


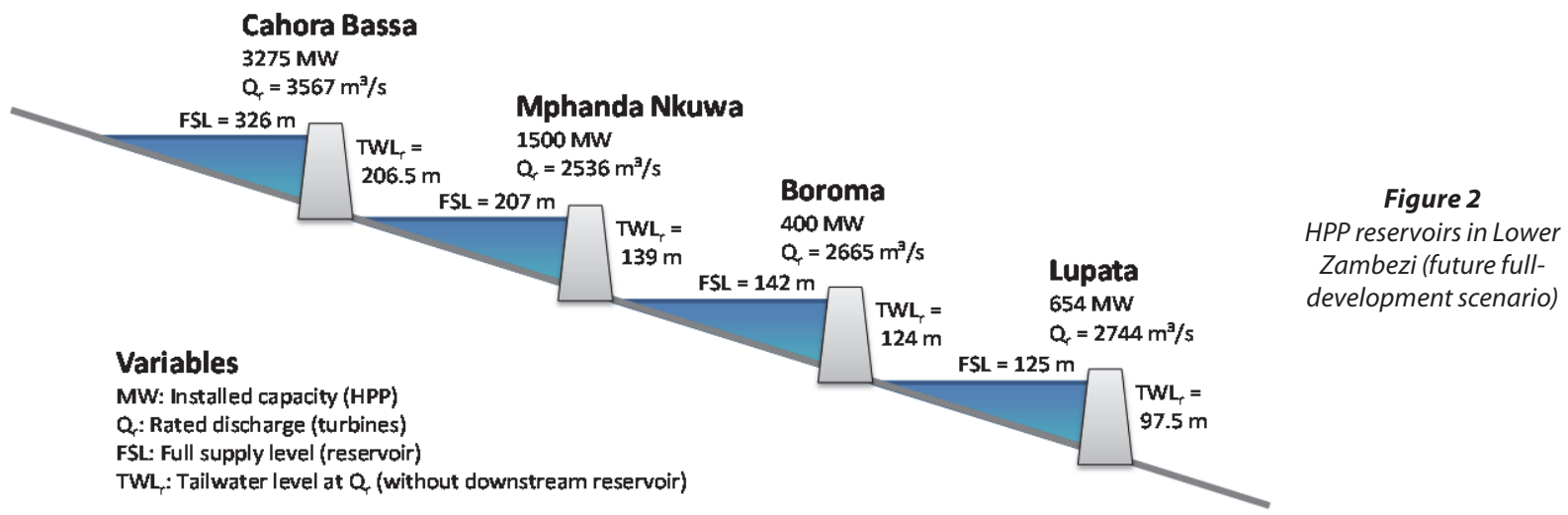

artificial reservoirs, especially Lake Kariba, the world's largest reservoir with respect to storage volume, affects seasonal runoff.

\section{DATA AND METHODS}

\section{Lower Zambezi reservoir model}

For the simulation of hydropower production, a daily reservoir operation and hydropower generation model is set up for the Lower Zambezi in HEC-ResSim 3.0. HEC-ResSim is freely available reservoir simulation software developed and maintained by the US Army Corps of Engineers, Hydrologic Engineering Center. As input, the model requires inflow data to the system, which can be based on streamflow measurements or simulations by precipitation-runoff models. Reservoirs are the integral component of the HEC-ResSim model, and a large number of properties for reservoirs can be specified. These include elevation-area-storage curves, evaporation, outlets, operation rules and downstream reservoir control on upstream tailwater levels.

The elevation-area-storage curve defines the basic properties of the reservoir for the mass balance accounting between inflows and outflows. This curve is also used for determining the evaporation from the surface area of the water body. The water level affects energy generation (hydraulic head) and spillway losses. Also, operation rules are defined based upon water level, by means of a water level guide curve. In the simulation, the model will preferentially try to keep the reservoir water level at the top of the guide curve elevation, while obeying all further defined rules (e.g. environmental flow requirements).
The changes in the guide curve define the seasonal characteristics of drawdown and filling.

Power plant specifications include installed capacity, rated discharge, tailwater levels, efficiencies, hydraulic losses. Spillway properties are usually defined by a curve giving the relationship between water level in the reservoir and spillway discharge. The HEC-ResSim model is especially apt to support the analysis of several alternative scenarios, which may differ in the inflow data, the operation rules, reservoir characteristics or the general reservoir network configuration.

In the HEC-ResSim Lower Zambezi reservoir model, two configurations of HPPs are considered: a historic configuration with only Cahora Bassa HPP with the current installed capacity of $2075 \mathrm{MW}$, and a future full-development scenario with the four HPPs Cahora Bassa (with an extended capacity of 3275 MW), Mphanda Nkuwa, Boroma and Lupata. The project of Chemba HPP further downstream is not considered in this study, as it might not be realised within the temporal scope of 2021-2050, the first future period analysed in this study.

For the future HPPs, different studies report different and partly contradicting characteristics. For the Lower Zambezi reservoir model, a consistent set of HPP characteristics is developed based on a synthesis of information reported by the World Bank (2010a, Vol. 3), Mepanda Uncua Feasibility Study (UTIP, 2001), Beilfuss (2001) and Mott MacDonald (2007), and on digital elevation model analysis for missing information about reservoir characteristics. The reservoirs and HPPs considered in the future full-development scenario are shown in Fig. 2, together with the main characteristics assumed in this study. An overview of these characteristics and other assumed HPP parameters is presented in Table 1.

\begin{tabular}{|c|c|c|c|c|c|}
\hline \multicolumn{6}{|c|}{$\begin{array}{c}\text { TABLE } 1 \\
\begin{array}{c}\text { Main characteristics of hydropower plants and reservoirs for historic conditions } \\
\text { and for assumed future full-development conditions }\end{array}\end{array}$} \\
\hline & \multirow{2}{*}{$\begin{array}{c}\text { Historic } \\
\text { Cahora } \\
\text { Bassa }\end{array}$} & \multicolumn{4}{|c|}{ Full development } \\
\hline & & $\begin{array}{l}\text { Cahora } \\
\text { Bassa }\end{array}$ & $\begin{array}{l}\text { Mphanda } \\
\text { Nkuwa }\end{array}$ & Boroma & Lupata \\
\hline Installed capacity (MW) & 2075 & 3275 & 1500 & 400 & 654 \\
\hline Rated discharge $\left(\mathrm{m}^{3} / \mathrm{s}\right)$ & 2260 & 3567 & 2536 & 2665 & 2743 \\
\hline Efficiency $(/)$ & 0.9 & 0.9 & 0.9 & 0.9 & 0.9 \\
\hline Gross head (m) & 105 & 105 & 68.7 & 17.5 & 27.5 \\
\hline Rated head (m) & 103.5 & 103.5 & 67 & 17 & 27 \\
\hline Hydraulic losses (m) & 1.5 & 1.5 & 1.7 & 0.5 & 0.5 \\
\hline Minimum operation level (m) & 295 & 295 & 195 & 132 & 115 \\
\hline Full supply level (FSL, m) & 326 & 326 & 207 & 142 & 125 \\
\hline Storage at min.op.level $\left(\mathrm{hm}^{3}\right)$ & 31762 & 31762 & 1480 & 10 & 361 \\
\hline Storage at FSL $\left(\mathrm{hm}^{3}\right)$ & 83466 & 83466 & 2530 & 144 & 1788 \\
\hline
\end{tabular}


The reservoir and hydropower generation model is evaluated for the energy production of Cahora Bassa in the period of 2000-2010, for which data of historic production are available. For this evaluation, simulations are based on the historic configuration and on observed inflow to Cahora Bassa reservoir (see overview of scenario simulations in Table 2). Historic operation rules are derived by analysing the actual operation data (water levels and outflows) of the period 2000-2010, leading to a monthly flood rule guide curve for target storage levels and a minimum release of $1400 \mathrm{~m}^{3} / \mathrm{s}$ throughout the year. Simulations of future hydropower production are based on the full-future hydropower development configuration with all four HPPs. For Cahora Bassa, historic operation rules are assumed also in these simulations. For the future HPPs downstream of Cahora Bassa, operation rules are defined by a guide curve with full supply level as constant target storage level throughout the year. Hydrological input is based on water balance simulations with climate model input data.

\section{Hydrological input scenarios}

For the evaluation of the Lower Zambezi reservoir model, observed inflow into Cahora Bassa reservoir is applied as hydrological input data. For all other scenario simulations, inflow time series are generated with the Zambezi DSS hydrological modelling tool (see scenario overview in Table 2). These inflow time series consider inflow to Cahora Bassa reservoir and lateral inflow of intermediate catchments to the downstream reservoirs. In addition, net evaporation from the reservoirs (precipitation minus evaporation) is taken from hydrological simulations with the Zambezi DSS. The hydrological model implemented in the Zambezi DSS tool comprises a water balance model simulating the formation of runoff from precipitation and a water allocation model simulating the impacts of natural and artificial reservoirs (e.g. Kariba reservoir) and water withdrawal on river discharge. A detailed description and evaluation of the performance of the Zambezi DSS is presented in Kling et al. (2014), who show that the Zambezi DSS has a high skill for simulation of river discharge. We evaluate the applicability of Zambezi DSS simulations for the Lower Zambezi reservoir model by repeating the hydropower simulations for 2000-2010 with simulated inflow and comparing the results with those obtained with observed inflow (see Table 2).

For the assessment of climate change impacts on hydropower production, two climate projections of two different Global Climate Models (GCMs) are considered: ECHAM5/ MPIOM of the German Max-Planck-Institut für Meteorologie (ECHAM) and CNRM-CM3 of the French Centre National de Recherche Météorologique (CNRM). GCM time series for precipitation and temperature for 1961 to 2100 , based on the A2 emission scenario for the $21^{\text {st }}$ century, were obtained from the WATCH project (WATCH, 2011). In the WATCH project, daily GCM simulations of three models were downscaled with quantile mapping with observed data to a half-degree spatial resolution. At the time of execution of this study, WATCH data were the only available downscaled and bias-corrected data for the Zambezi basin. We selected the model data showing the most consistent decrease in precipitation over the Zambezi basin as a drying scenario, and the model data showing a future increase in precipitation as a wetting scenario. For the application with the Zambezi DSS, an additional small bias correction is applied to the aggregated monthly data, such that the corrected GCM data matches the climatology of 1961-1990 for precipitation data of the Global Precipitation Climatology Centre (GPCC, version 5; Schneider et al., 2013) and temperature data of the Climate Research Unit (CRU, version TS 3.1; Harris et al., 2013). Changes in potential evapotranspiration are derived from temperature changes, assuming an increase of $+2.5 \%$ with a temperature increase of $1^{\circ} \mathrm{C}$. This relationship is based on a sensitivity analysis using the Penman-Monteith evapotranspiration procedure with data of the FAO CLIMWAT data set.

The climate projections of ECHAM represent a future drying scenario, with a precipitation decrease of $-2 \%$ for 2021-2050 and of $-5 \%$ for 2071-2100, as compared with 1961-1990, averaged over the entire Zambezi basin upstream of Tete. The wetting scenario of CNRM projects an increase in precipitation of $+6 \%$ for $2021-2050$ and of $+7 \%$ for $2071-2100$. Temperature projections of both models are rather similar, with an increase of $+1.4^{\circ} \mathrm{C}(\mathrm{ECHAM})$ and $+1.7^{\circ} \mathrm{C}(\mathrm{CNRM})$ for $2021-2050$ and $+4.7^{\circ} \mathrm{C}$ (ECHAM) and $+4.8^{\circ} \mathrm{C}(\mathrm{CNRM})$ for 2071-2100.

The impact of each climate model projection is analysed for these two periods, the near-future period 2021-2050, and the far-future period 2071-2100. An overview of all scenarios investigated in detail in this study is given in Table 2, outlining the respective time period, inflow data and hydropower characteristics. In all scenarios, irrigation withdrawal assumptions for the entire Zambezi basin are based on the World Bank (2010a, Vol.4) 'current irrigation' scenario. While assumptions concerning irrigation and the hydropower system might not be fully valid for a distant future in 2071-2100, it is important to assess climate change impacts for this far-future period, because the full effect of climatic changes can be more clearly distinguished from natural variability in the second half of the $21^{\text {st }}$ century.

Inflow into Cahora Bassa reservoir as simulated by the Zambezi DSS with the two climate model input data sets is shown in Fig. 3. In the wetting CNRM future scenarios, inflow to Cahora Bassa increases mainly in the wet season, leading to

\begin{tabular}{|l|l|l|l|l|}
\hline \multicolumn{7}{|c|}{ Overview of applied scenarios } \\
\hline Scenario & Period & $\begin{array}{l}\text { Inflow to } \\
\text { Cahora Bassa }\end{array}$ & $\begin{array}{l}\text { Climate input for } \\
\text { inflow simulation }\end{array}$ & $\begin{array}{l}\text { Hydropower } \\
\text { characteristics }\end{array}$ \\
\hline Reservoir model evaluation & $2000-2010$ & Observed & - & Historic \\
\hline Zambezi DSS inflow evaluation & $2000-2010$ & Simulated & Observations & Historic \\
\hline Reference CNRM & $1961-1990$ & Simulated & CNRM climate model & Full development \\
\hline Near-future CNRM / wetting & $2021-2050$ & Simulated & CNRM climate model & Full development \\
\hline Far-future CNRM / wetting & $2071-2100$ & Simulated & CNRM climate model & Full development \\
\hline Reference ECHAM & $1961-1990$ & Simulated & ECHAM climate model & Full development \\
\hline Near-future ECHAM / drying & $2021-2050$ & Simulated & ECHAM climate model & Full development \\
\hline Far-future ECHAM / drying & $2071-2100$ & Simulated & ECHAM climate model & Full development \\
\hline
\end{tabular}



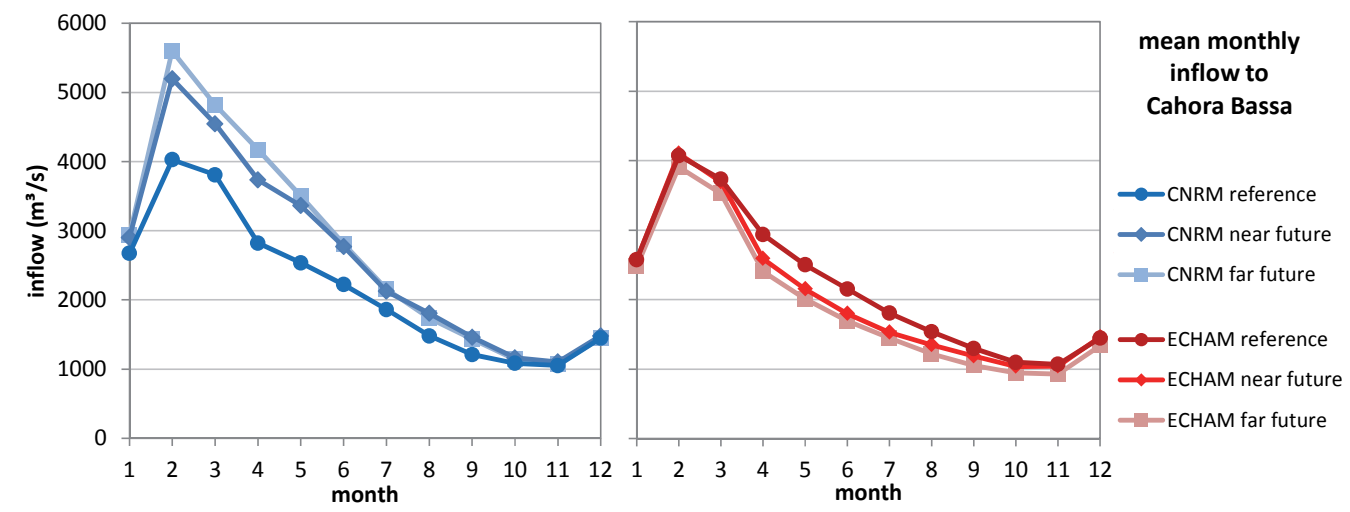

Figure 3

30-year means of monthly inflow to

Cahora Bassa reservoir simulated by the

Zambezi DSS for both

climate models and

three periods

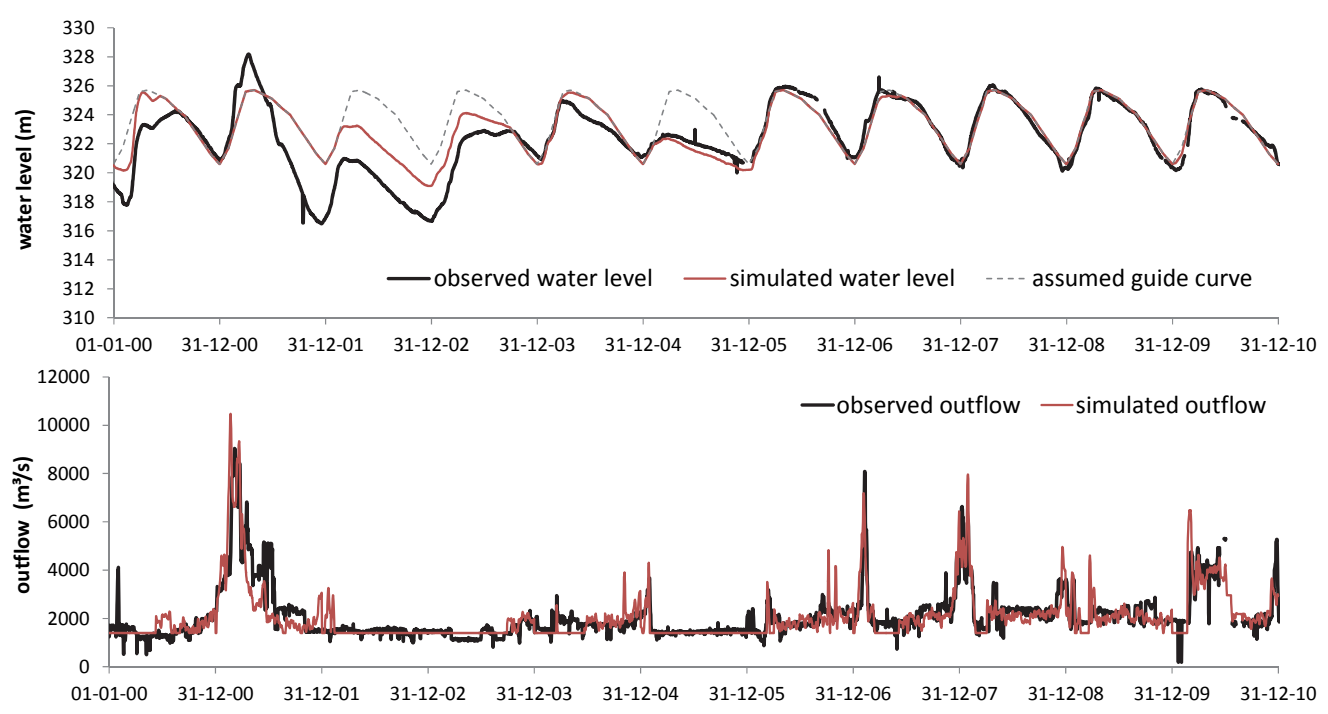

Figure 4

Simulated and observed water levels in Cahora Bassa reservoir (top) and outflow from Cahora Bassa HPP (bottom) in the years 2000 to 2010. Simulations based on observed inflow (reservoir model evaluation scenario).

a higher seasonal variability of inflows. With drying ECHAM climate, a decrease is simulated as a general shift to lower inflow throughout the year.

All described time-series of meteorological input data and simulated inflow are available for the entire Zambezi basin for detailed assessment and download at the online version of the Zambezi DSS (INGC, 2014).

\section{RESULTS}

\section{Historic energy production in Cahora Bassa HPP}

Simulation results with the current characteristics of Cahora Bassa HPP, historic climate data (for reservoir evaporation losses) and historic observed inflow to the reservoir as input (reservoir model evaluation scenario) show a high concordance between observed and simulated water level in the reservoir (Fig. 4 top) and observed and simulated outflow (Fig. 4 bottom).

Figure 5 compares observed energy production with simulations based on both observed inflow to Cahora Bassa reservoir and inflow simulated by the Zambezi DSS (with observed precipitation and temperature as input). The close match of the two simulations shows the applicability of Zambezi DSS inflow simulations for hydropower simulations for the Lower Zambezi. Generally, hydropower simulation results are higher than the observations, especially at the beginning of the evaluation period 2000 to 2010 . The last 6 years show a good match, with an overall rising trend represented well in the simulations. Differences between simulation and observation

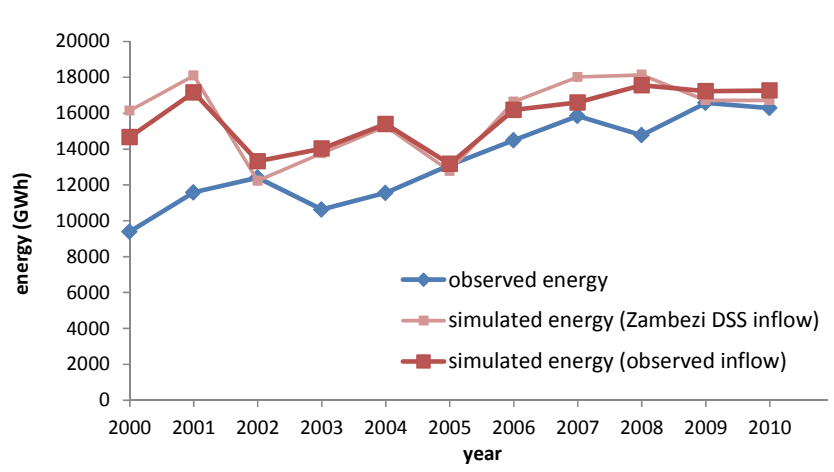

Figure 5

Simulated and observed annual energy generation at Cahora Bassa HPP. Simulations based on observed inflow (reservoir model evaluation scenario) and simulated inflow (Zambezi DSS inflow evaluation scenario)

are related to the fact that the full capacity of turbines was not utilised, but water was instead also released via the spillway, even during low-flow periods. Such a sub-optimal operation of the HPP may have been related to various constraints, such as turbine availability (maintenance, refurbishment), transmission capacity, energy demand, market conditions or management decisions. Therefore, it is reasonable that the actual historic generation was lower than in the simulation, which gives an upper limit of generation not considering the constraints listed above. 


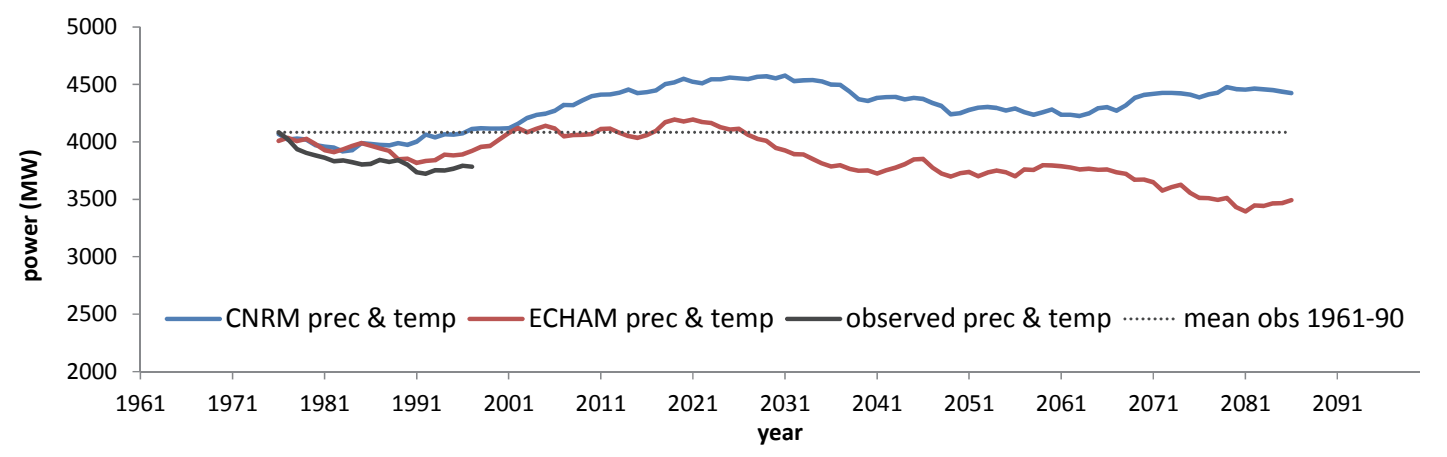

Figure 6

30-year moving average of simulated powergeneration (total of all four HPPs) for climate input from observations and from climate models CNRM and ECHAM

\begin{tabular}{|c|c|c|c|}
\hline - Cahora Bassa ECHAM & Mphanda Nkuwa ECHAM & Boroma ECHAM & Lupata ECHAM \\
\hline$\square$ Cahora Bassa CNRM & $\square$ Mphanda Nkuwa CNRM & $\square$ Boroma CNRM & 口 Lupata CNRM \\
\hline
\end{tabular}

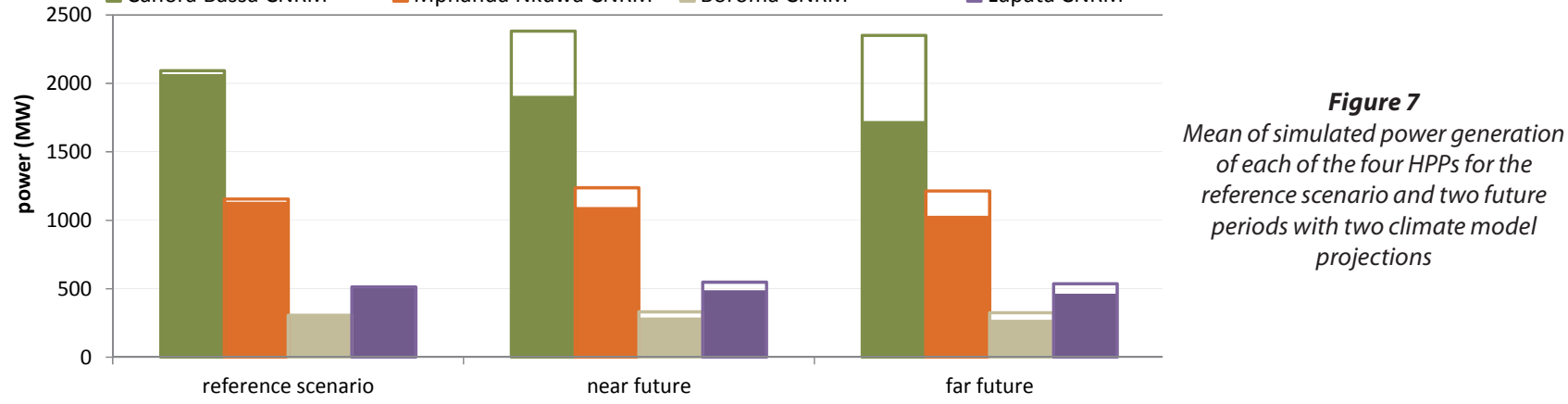

\section{Hydropower generation under changing climate conditions}

The strong impact of climate model precipitation trends is clearly shown in simulation results with a future drying climate as projected by ECHAM and a future wetting climate as projected by CNRM. The 30 -year running mean of simulated total hydropower production in all four HPPs in Fig. 6 shows the falling trend of production in the $21^{\text {st }}$ century in the simulations with ECHAM data. After around 2060, the decrease exceeds the range of previous natural variability. With CNRM data, hydropower production remains on higher levels than in the historic period despite higher temperature and evaporation.

Long-term mean power generation of the near-future period 2021-2050 is $4500 \mathrm{MW}$ with CNRM input data and around $3800 \mathrm{MW}$ with ECHAM input data. Results for the far-future period 2071-2100 are around $4400 \mathrm{MW}$ (CNRM) and $3500 \mathrm{MW}$ (ECHAM). Compared to the respective simulations for the reference period of 1961-1990, this is an increase with CNRM of $+11 \%$ (near future) and $+9 \%$ (far future), and a decrease with ECHAM of $-6 \%$ and $-13 \%$.

Table 3 displays these changes in total production in the climate change scenarios together with the respective climate change signals for precipitation and temperature. Both decreases and increases of hydropower generation are larger than the underlying precipitation changes, showing the high sensitivity of runoff and hydropower generation to precipitation trends. The comparison of results for the far-future period with those of the near-future period emphasizes the important effect of temperature and resulting evaporation. In the considerably warmer far-future period of 2071-2100, the increase of hydropower production due to higher precipitation in the wetting scenario is markedly lower than in the near-future period of 2021-2050. In the drying scenario, the hydropower decrease is considerably higher with stronger warming in the far-future period.

Detailed hydropower modelling enables analyses of effects for each facility in the future cascade of reservoirs and HPPs. Mean hydropower production at each HPP is shown in Fig. 7 for the historic reference scenario and the two future periods under climate change impact. In the ECHAM scenarios, power generation at Cahora Bassa HPP decreases from over $2000 \mathrm{MW}$ in the reference period to around $1900 \mathrm{MW}$ in 2021-2050 (near future), and to almost $1700 \mathrm{MW}$ in 2071-2100 (far future). This implies a decrease in load factor from 0.65 to 0.53 (Table 4). The relative decrease in hydropower production at Cahora Bassa HPP of almost $-8 \%$ for the first future period and almost $-17 \%$ for the second period is higher than

\begin{tabular}{|l|l|c|c|c|}
\hline \multicolumn{5}{|c|}{ TABLE 3} \\
\begin{tabular}{|l} 
Simulated changes in hydropower in climate change scenarios, compared to the \\
reference scenario, and underlying temperature and precipitation changes
\end{tabular} \\
\hline Scenario & Period & $\begin{array}{c}\text { Temperature } \\
\text { change }\left({ }^{\circ} \mathrm{C}\right)\end{array}$ & $\begin{array}{c}\text { Precipitation } \\
\text { change }(\%)\end{array}$ & $\begin{array}{c}\text { Hydropower } \\
\text { change (\%) }\end{array}$ \\
\hline Near-future CNRM / wetting & $2021-2050$ & +1.4 & $+6 \%$ & $+11 \%$ \\
\hline Far-future CNRM / wetting & $2071-2100$ & +4.7 & $+7 \%$ & $+9 \%$ \\
\hline Near-future ECHAM / drying & $2021-2050$ & +1.7 & $-2 \%$ & $-6 \%$ \\
\hline Far-future ECHAM / drying & $2071-2100$ & +4.8 & $-5 \%$ & $-13 \%$ \\
\hline
\end{tabular}




\begin{tabular}{|c|c|c|c|c|c|c|c|c|}
\hline \multicolumn{9}{|c|}{$\begin{array}{l}\text { TABLE } 4 \\
\text { Results for power generation and resulting load factor (ratio of generated power/installed capacity) }\end{array}$} \\
\hline & \multicolumn{4}{|c|}{ Power generation (MW) } & \multicolumn{4}{|c|}{ Load factor (MW/installed MW) } \\
\hline Scenario & $\mathrm{CB}$ & $\mathrm{MN}$ & BO & LU & $\mathrm{CB}$ & $\mathrm{MN}$ & BO & LU \\
\hline Installed capacity & 3275 & 1500 & 400 & 654 & & & & \\
\hline \multicolumn{9}{|l|}{ CNRM / wetting } \\
\hline Reference & 2091 & 1155 & 307 & 513 & 0.64 & 0.77 & 0.77 & 0.78 \\
\hline Near-future & 2382 & 1238 & 331 & 548 & 0.73 & 0.83 & 0.83 & 0.84 \\
\hline Far-future & 2350 & 1214 & 324 & 536 & 0.72 & 0.81 & 0.81 & 0.82 \\
\hline \multicolumn{9}{|l|}{ ECHAM / drying } \\
\hline Reference & 2066 & 1134 & 301 & 505 & 0.63 & 0.76 & 0.75 & 0.77 \\
\hline Near-future & 1909 & 1097 & 290 & 489 & 0.58 & 0.73 & 0.73 & 0.75 \\
\hline Far-future & 1725 & 1032 & 273 & 463 & 0.53 & 0.69 & 0.68 & 0.71 \\
\hline
\end{tabular}

CB - Cahora Bassa, MN - Mphanda Nkuwa, BO - Boroma, LU - Lupata

\begin{tabular}{|c|c|c|c|c|c|c|c|c|c|c|c|c|}
\hline \multicolumn{13}{|c|}{$\begin{array}{c}\text { TABLE } 5 \\
\text { Results for total outflow and its components, turbined discharge and spillway discharge }\end{array}$} \\
\hline \multirow[b]{2}{*}{ Scenario } & \multicolumn{4}{|c|}{ Total outflow $\left(\mathrm{m}^{3} / \mathrm{s}\right)$} & \multicolumn{4}{|c|}{ Turbined discharge $\left(\mathrm{m}^{3} / \mathrm{s}\right)$} & \multicolumn{4}{|c|}{ Spillway discharge $\left(\mathrm{m}^{3} / \mathrm{s}\right)$} \\
\hline & CB & MN & BO & LU & CB & MN & BO & LU & CB & MN & BO & LU \\
\hline \multicolumn{13}{|c|}{ CNRM / wetting } \\
\hline Reference & 2113 & 2329 & 2340 & 2558 & 2076 & 2069 & 2109 & 2203 & 36 & 260 & 232 & 355 \\
\hline Near-future & 2563 & 2813 & 2825 & 3071 & 2408 & 2220 & 2280 & 2363 & 155 & 593 & 545 & 709 \\
\hline Far-future & 2652 & 2928 & 2941 & 3201 & 2383 & 2179 & 2236 & 2319 & 269 & 749 & 706 & 882 \\
\hline \multicolumn{13}{|c|}{ ECHAM / drying } \\
\hline Reference & 2111 & 2324 & 2335 & 2545 & 2063 & 2032 & 2070 & 2169 & 48 & 293 & 266 & 376 \\
\hline Near-future & 1971 & 2220 & 2233 & 2481 & 1909 & 1965 & 1997 & 2102 & 63 & 254 & 236 & 379 \\
\hline Far-future & 1823 & 2099 & 2113 & 2373 & 1738 & 1850 & 1880 & 1990 & 85 & 249 & 233 & 382 \\
\hline
\end{tabular}

CB - Cahora Bassa, MN - Mphanda Nkuwa, BO - Boroma, LU - Lupata

the total decrease for all HPPs. Accordingly, the decrease in the other three HPPs is lower, with around $-3 \%$ (near future) and between $-8 \%$ and $-9 \%$ (far future). Detailed figures of simulated hydropower production and resulting load factors for all four HPPs are given in Table 4.

CNRM results show similar characteristics with opposite sign, with a higher increase in power generation at Cahora Bassa (14\% for the near-future period, $12 \%$ for the far-future period) than at the other three HPPs (between $7 \%$ and $8 \%$ for the near-future period and around 5\% for the far-future period). This shows that the large Cahora Bassa reservoir reduces the impact of climate variability on the downstream HPPs.

An analysis of simulated turbined discharge for Cahora Bassa HPP shows higher decreases (in the drying scenarios) or lower increases (in the wetting scenarios) than the respective changes in total outflow (Table 5). This is due to increasing spillway losses in both scenarios, but especially in the CNRM wetting scenarios. These results with simulations based on the existing operation rules show the potential of adapted operation rules at Cahora Bassa HPP as a means of adapting to changing climate conditions. In the downstream reservoirs - in accordance with the results for generated hydropower changes in turbined discharge are relatively smaller due to the operation of Cahora Bassa HPP. As a result of the lower storage volumes and lower rated discharges of the downstream reservoirs, spillway discharges are generally higher at downstream HPPs.

The impact of climate change scenarios on seasonal variations of hydropower production is shown exemplarily for the two largest HPPs, Cahora Bassa and Mphanda Nkuwa in Fig. 8. Additionally, Fig. 8 shows box-plots of annual hydropower production at the respective HPP, indicating the median and the range of annual production values. Generally, seasonal variability is lower at the downstream Mphanda Nkuwa HPP (Fig. 8, right) than at Cahora Bassa (Fig. 8, left), as an effect of reservoir operation at Cahora Bassa. In the wetting CNRM scenario (Fig. 8, top), markedly higher power generation in the first half of the year leads to an overall increased seasonal variability at both HPPs in future periods. In the drier ECHAM scenario (Fig. 8, bottom), power generation in future periods is significantly lower throughout the year at Cahora Bassa, leading to lower seasonal variability. At Mphanda Nkuwa, power generation in the wet season also remains high in future (drier) periods, but falls to lower levels in the dry season, thus increasing the seasonal variability. The box-plots show that interannual variability, represented by the range between the $25 \%$ and the $75 \%$-quartile and the $5 \%$ - and the $95 \%$-quantile, is also lower at the downstream Mphanda Nkuwa HPP than at Cahora Bassa, again as an effect of reservoir operation at Cahora Bassa. While the trends in the climate scenarios are apparent for the median values, no clear effect of climate change on interannual variability can be deduced from the analysis in Fig. 8 .

\section{DISCUSSION}

Applying one drying and one wetting climate scenario, as presented here, can be regarded as a sensitivity analysis based on physically-based climate model data. The described scenarios of ECHAM and CNRM under the A2 emission scenario are 

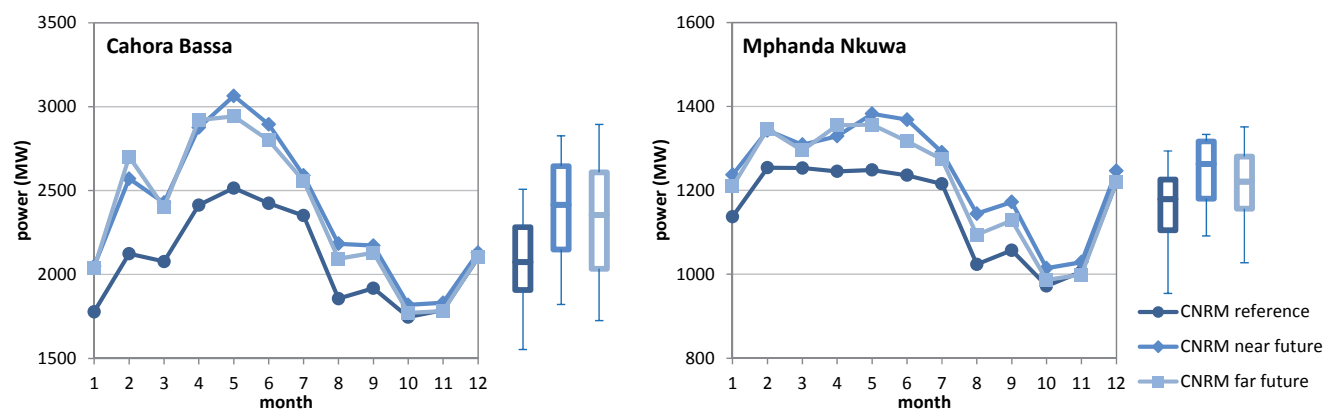

\section{Figure 8 \\ Simulated annual and seasonal power generation in the three analysed periods in Cahora Bassa (left) and Mphanda Nkuwa (right) for CNRM climate (top) and ECHAM climate (bottom). Monthly means illustrate seasonality, box-plots display spread in annual means by showing median, $25 \%$ - and $75 \%$ quartiles (boxes) and $5 \%$ - and 95\%-quantiles (whiskers).}
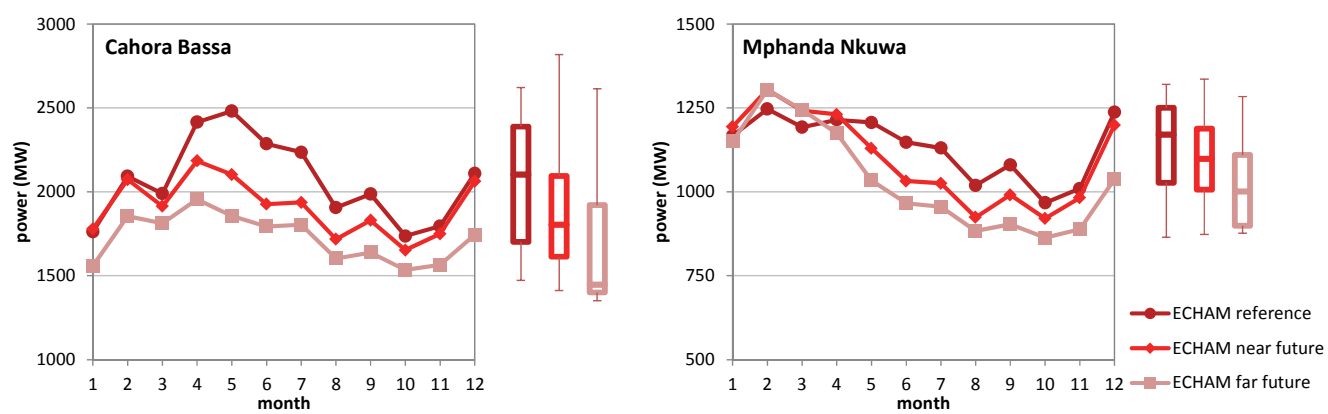

considered moderate and plausible projections of increase or decrease in basin-averaged precipitation. As the Zambezi basin is located in a region of transition of consistently projected precipitation decrease (to the south) and increase (to the north; Christensen et al., 2007), other models show a wider range of possible precipitation changes. Beck and Bernauer (2011) show a range of $+11 \%$ to $-28 \%$ for $16 \mathrm{GCMs}$ with the $\mathrm{A} 2$ emission scenario for 2050 for the entire Zambezi basin. Harrison and Whittington (2002) analyse three GCM projections for the 2080s for the basin upstream of Kariba, which show decreases in precipitation, between $-2 \%$ and $-18 \%$. Kling et al. (2014) evaluate scenarios from three Regional Climate Models (RCMs) from the ENSEMBLES project (emission scenario A1B) for the basin upstream of Tete, which also coincide in projecting a decrease in precipitation between $-1 \%$ and $-6 \%$ for $2021-2050$ and between $-9 \%$ and $-18 \%$ for $2071-2100$. The World Bank (2010b), focusing on Mozambique, states that of five analysed GCMs some show increases and some decreases. For temperature, the published projections are within a much smaller range and generally very similar to those assumed in the present study.

Updated climate simulations based on the new concept of Representative Concentration Pathways (RCPs) instead of emission scenarios, as adopted for the IPCC Assessment Report 5 , have recently become available. Downscaled projections by the University of Cape Town's Climate Systems Analysis Group (CSAG) for the Zambezi basin are currently analysed in a follow-up project. First results point towards higher accordance of different models in projecting a decrease in precipitation in the region. A new ensemble of Regional Climate Model projections for Africa will soon be available from the Coordinated Regional Climate Downscaling Experiment for Africa (CORDEX-Africa, 2014) and will support the analysis of climate uncertainties in the region.

In addition to the uncertainty related to future climate, the hydrological model applied for the inflow simulations contributes to the overall modelling uncertainty. Kling et al. (2014) show the generally good performance of the hydrological simulations of the Zambezi DSS and demonstrate the good ability of the model to accurately simulate the basin response to precipitation changes. However, the simulations for Cahora Bassa inflow for the period 1961-1990, driven by bias-corrected GCM data, do exhibit small biases with respect to observed inflow. This also leads to small discrepancies between the hydropower simulation results of the reference scenarios of the two climate models, as apparent in Table 4 and Table 5. For the sum of power generation of the four considered HPPs, the deviation from a simulation with inflow based on observed precipitation and temperature is $0.4 \%$ for input based on CNRM data and 1.8\% for ECHAM input. As these biases are markedly lower than the climate change effect, they are considered acceptable.

Due to the high sensitivity of runoff and resulting hydropower generation to changes in precipitation, results of other studies differ from the results presented here according to the respective assumptions of future rainfall. The World Bank (2010b), reporting on simulations for all Mozambican river basins, projects only small decreases in hydropower production of $-1.4 \%$ in all but the most pessimistic of their five investigated scenarios. The studies reviewed by Beilfuss (2012) suggest a more negative impact of climate change on hydropower. SWRSD (2011) expect reductions of inflow to Cahora Bassa reservoir of over $-40 \%$ in sensitivity analyses assuming precipitation decreases of $-15 \%$. From a combined investigation of effects of irrigation development and a warming climate, the World Bank (2010a, Vol. 2) expects an average reduction of around $-32 \%$ in hydropower production at Cahora Bassa and Mphanda Nkuwa due to both investigated impacts, with a climate change impact of around $-23 \%$. Also Beck and Bernauer (2010) show potentially drastic effects of a combination of strong reduction in precipitation and increase in irrigation and industrial water demand on inflow to Cahora Bassa, with decreases of up to $-65 \%$. Both studies assume enormous expansions of irrigation areas and resulting evaporative losses. In line with recent results by Kling et al. (2014), they reveal the strong possible impact of water management decisions compared with climate change effects. However, investigations combining water demand and climate trends do not clearly show the impacts of climate change alone, which is the focus of the study presented here. 
An important result of this study is that the operation of Cahora Bassa reservoir, which generally reduces natural variability in streamflow, also reduces the impact of climate change induced variability for the downstream HPPs. The larger upstream Kariba reservoir has a similar impact on runoff variability downstream, i.e., for inflow to Cahora Bassa reservoir. In the inflow simulations of the Zambezi DSS, the operation of Kariba is considered with a specified guide curve and minimum release. The specific impact of Kariba in buffering the effects of climate change on Zambezi River discharge and resulting hydropower production is not analysed here, but is considered an important issue for further investigation.

Seasonal variability, which is shown to increase under the future CNRM wetting climate and to decrease under the ECHAM drying climate, is the main issue for environmental impact of reservoir operation. While not analysed in detail in this study, sensitivity analyses showed that changed operation rules at Cahora Bassa reservoir can enhance hydropower production under changed climatic conditions. Implementation of environmental flow releases, however, as also shown by Beilfuss (2010), considerably reduce hydropower generation, especially in a drying climate.

\section{CONCLUSIONS}

The presented study investigates possible impacts of a changing future climate on future hydropower production in the Lower Zambezi, considering the extended Cahora Bassa HPP and the planned downstream facilities Mphanda Nkuwa, Boroma and Lupata. Climate change scenarios applied for the complex hydropower modelling of this study are based on bias-corrected climate model data of two recent GCMs, representing one future wetting and one future drying climate. This approach can be regarded as a sensitivity analysis based on physicallybased climate modelling. All meteorological and hydrological input data sets for the entire Zambezi basin are publicly available in an online decision support system, the Zambezi DSS (INGC, 2014; Kling et al., 2014).

The scenario simulations in this study yield the following main findings:

- A plausible range of future hydropower generation in the Lower Zambezi River affected by possible changes in climate is presented. In a future wetting climate, hydropower production is projected to increase between $+11 \%$ (near future) and $+9 \%$ (far future), as compared to a historic reference scenario. Clearly, possible future trends of increasing precipitation might compensate negative effects of rising temperatures. For a drying climate, a decrease of $-6 \%$ (near future) and $-13 \%$ (far future) is simulated.

- Sensitivity of hydropower generation to precipitation changes is high. Relative increases or decreases in production, in the wetting and drying scenarios, are significantly higher than the underlying precipitation change signals.

- The high sensitivity of future hydropower generation to future trends in precipitation shows the importance of tackling the high uncertainty in precipitation projections in climate modelling results for the region. Progress in this field can be expected from new RCM development in the framework of CORDEX-Africa (CORDEX-Africa, 2014).

- Cahora Bassa HPP is more susceptible to climate change due to its high rated discharge in the future extended conditions. In a wetting climate, resulting higher discharge can largely be used for hydropower production. In a drying climate, the high potential production cannot be fulfilled due to limited water availability.

- The downstream hydropower plants of Mphanda Nkuwa, Boroma and Lupata are more resilient to climate change due to their lower rated discharges. They cannot make full use of increasing discharge, but are also less affected by decreasing discharge. Furthermore, the operation of the large upstream Cahora Bassa reservoir reduces seasonal and decadal variability in discharge and therefore also reduces the impact of climate change on downstream HPPs.

The results of this study raise important questions about future production in the proposed hydropower projects, and consequently about their financial viability. Climate risks should therefore be taken into account in decisions on installed capacities and in financial assessments.

\section{ACKNOWLEDGEMENTS}

This research was carried out for the National Institute of Disaster Management (INGC), Mozambique, in collaboration with HYDROC, Germany. Input data for hydropower modelling is based on data by the Global Precipitation Climatology Centre in Germany, the Climate Research Unit in the UK and on data sets from the EU WATCH project. The constructive comments of two anonymous reviewers are gratefully acknowledged.

\section{REFERENCES}

BECK L (2010) Transboundary water allocation in the Zambezi River Basin. PhD thesis, Eidgenössische Technische Hochschule ETH Zürich.

BECK L and BERNAUER T (2011) How will combined changes in water demand and climate affect water availability in the Zambezi river basin? Glob. Environ. Change 21 (3) 1061-1072.

BEILFUSS R (2001) Prescribed flooding and restoration potential in the Zambezi Delta, Mozambique. Working paper \#3, Program for the sustainable management of Cahora Bassa Dam and the Lower Zambezi Valley. International Crane Foundation, Barabou. 72 pp.

BEILFUSS R (2010) Modelling trade-offs between hydropower generation and environmental flow scenarios: a case stuy of the Lower Zambezi River Basin, Mozambique. Int. J. River Basin Manage. 8 (3-4) 331-347.

BEILFUSS R (2012) A Risky Climate for Southern African Hydro. Assessing Hydrological Risks and Consequences for Zambezi River Dams. International Rivers, Berkeley. 56 pp.

CHRISTENSEN JH, HEWITSON B, BUSUIOC A, CHEN A, GAO X, HELD I, JONES R, KOLLI RK, KWON W-T, LAPRISE R, MAGAÑA RUEDA V, MEARNS L, MENÉNDEZ CG, RÄISÄNEN J, RINKE A, SARR A and WHETTON P (2007) Regional climate projections. In: Solomon S, Qin D, Manning M, Chen Z, Marquis M, Averyt KB, Tignor M and Miller HL (eds.) Climate Change 2007: The Physical Science Basis. Contribution of Working Group I to the Fourth Assessment Report of the Intergovernmental Panel on Climate Change. Cambridge University Press, Cambridge and New York.

CORDEX-AFRICA (2014) Coordinated Regional Climate Downscaling Experiment in Africa. URL: http://start.org/cordex-africa/ (Accessed 10 July 2014).

HARRIS I, JONES PD, OSBORN TJ and LISTER DH (2013) Updated high-resolution grids of monthly climatic observations. Int. J. Clim. 34 (3) 623-642.

HARRISON GP and WHITTINGTON HW (2002) Susceptibility of the Batoka Gorge hydroelectric scheme to climate change. J. Hydrol. 264 230-241.

INGC (2014) Online version of Zambezi DSS, published by the National Institute of Disaster Management (INGC), Mozambique. URL: http://www.zdss.ingc.gov.mz/ (Accessed 10 July 2014). 
IPCC (2001) Climate Change 2001: Impacts, Adaptation, and Vulnerability. Contribution of Working Group II to the Third Assessment Report of the Intergovernmental Panel on Climate Change. Cambridge University Press, Cambridge. 970 pp.

KLING H, STANZEL P and PREISHUBER M (2014) Impact modelling of water resources development and climate scenarios on Zambezi River discharge. J. Hydrol.: Reg. Stud. 1 17-43.

MOTT MACDONALD (2007) Rapid Assessment - Final Report. Integrated Water Resources Management Strategy for the Zambezi River Basin. SADC-WD, Zambezi River Authority, SIDA, DANIDA, Norwegian Embassy, Lusaka. 188 pp.

SALEWICZ KA (1996) Impact of climate change on the Lake Kariba hydropower scheme. In: Kaczmarek Z, Strzepek KM, Somlyody and Priazhinskaya V (eds.) Water Resources Management in the Face of Climatic/Hydrological Uncertainties. Kluwer Academic Publishers, Rotterdam.

SAPP (2012) Annual Report 2012. Southern African Power Pool, Harare. 73 pp.

SCHNEIDER U, BECKER A, FINGER P, MEYER-CHRISTOFFER A, ZIESE M and RUDOLF B (2013) GPCC's new land surface precipitation climatology based on quality-controlled in situ data and its role in quantifying the global water cycle. Theor. Appl. Climatol. 115 (1-2) 15-40.

SWRSD (2011) Dam synchronization and flood releases in the Zambezi River Basin Project. Report in the framework of the
'Transboundary Water Management in SADC' programme. Southern African Development Community, Gabarone. 72 pp.

TILMANT A, BEEVERS L and MUYUNDA B (2010) Restoring a flow regime through the coordinated operation of a multireservoir system: The case of the Zambezi River basin. Water Resour. Res. 46 (7) W07533.

URBIZTONDO RJ (1992) Modelling of climate change impacts on the Upper Zambezi River Basin. MSc thesis, University of Colorado.

UTIP (2001) Mepanda Uncua and Cahora Bassa North Project Feasibility Study. Final Environmental Impact Assessment. Technical Unit for the Implementation of Hydropower Projects (UTIP), Maputo.

WATCH (2011) WATCH 20th Century Model Output Datasets \& WATCH 21st Century Model Output. URL: http://www.eu-watch. org (Accessed 15 December 2011)

WORLD BANK (2010a) The Zambezi River Basin: A Multi-Sector Investment Opportunities Analysis. The World Bank, Washington. Volumes 1-4.

WORLD BANK (2010b) Economics of Adaptation to Climate Change Mozambique. The World Bank, Washington. 104 pp.

YAMBA FD, WALIMWIPI H, SUMAN J, ZHOU P, CUAMBA B and MZEZEWA C (2011) Climate change/variability implications on hydroelectricity generation in the Zambezi River Basin. Mitigation Adapt. Strateg. Glob. Change 16 617-628. 